\title{
Digitalization as a key factor in the development of the regional agricultural sector
}

\author{
Fatima Karaeva ${ }^{1, *}$, Rameta Shokumova ${ }^{1}$, Pavel Zhufan ${ }^{2}$, and Asiyat Temrokova ${ }^{1}$ \\ ${ }^{1}$ Kabardino-Balkarian State Agricultural University named after V.M. Kokova, Lenin Avenue, 1V, \\ 360030 Nalchik, Russia \\ ${ }^{2}$ Mendel University of Agriculture and Forestry, Zemědělská 1, 61300, the Czech Republic
}

\begin{abstract}
Modern realities of sustainable development of the agro-industrial complex require new trends and tools. The article considers digital technologies as one of the key parameters for the development of the agricultural sector of the economy in increasing production efficiency. The greatest emphasis is placed on the formation of territorial innovative models of the agrarian sector of the republic's economy, considering the growth of the gross domestic product, but at this time, the agrarian sector is not technologically modernized enough for the development of these platforms. First of all, it is necessary to resolve the issues of staffing with highly qualified specialists, which will allow to deploy digital technologies and reduce costs by $23 \%$, since the average cost savings in land use using GPS navigation technologies is $11-14 \%$, with differentiated fertilization $-8-12 \%$. In addition to the growth of economic components, this development path ensures the environmental safety of agricultural production.
\end{abstract}

\section{Introduction}

Currently, digitalization is one of the most promising trends and tools of the state to achieve balanced sustainable economic development. Digitalization as a key factor is increasingly penetrating all segments of the region's agricultural sector and is gaining momentum by introducing digital innovations.

The role of digital technology in the development of the agricultural sector is great and consists in providing the population with safe, vital important products, in reducing costs, increasing the environmental, economic and production efficiency of production, which will attract workers of new professions to agriculture.

In this regard, a clear vector for the development of digitalization should be developed in the agricultural sector, aimed at the effectiveness of the implementation of technological operations based on digital platforms, allowing to achieve high results.

*Corresponding author: fatima64@mail.ru 


\section{Materials and methods}

The new realities of strategic successful digitalization require a variety of industries in the application of the development of digital approaches aimed at the needs of market-oriented tasks, closely related to the practice of their implementation. To implement such approaches, standardized raw data is needed and demanded, allowing for the analysis of indicators, considering the emerging problems, and at the same time the development of recommendations aimed at action. Topical scientific publications within the framework of the digitalization of the economy, operational information arrays of the relevant ministries and departments of the republic have been examined. Following methods were applied in the process of working on the article: observation, logical, structural analysis, synthesis, as well as techniques of economic and statistical analysis.

\section{Results and discussion}

The digital economy can be defined as the integrity of the system of social-and-economic relations based on the use of digital information and communication technologies. It should be noted that the digital economy is basically aimed to simplify the interaction of participants in the production process both within the organization and in interaction with various external actors within the production process management framework.

This infrastructural superstructure should be considered conjointly with real production and consider its impact on the efficiency of technological processes. To obtain a general economic effect, the digital technologies should be implemented in parallel with the development of "traditional" production.

Digitalization may be considered at various levels (Fig. 1), and various research methods have been proposed by Russian and foreign economists [1].

The application of most of the methods is based on the collection of statistical information, which sometimes is not entirely accurate for assessing the real situation and, as a rule, the problem consists in the actual data collection [2].

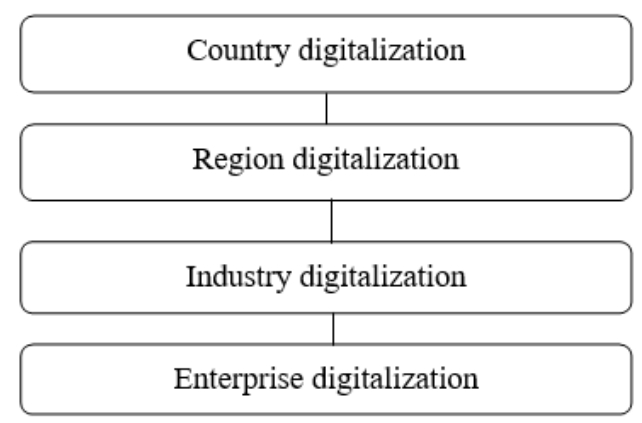

Fig. 1. Economic system digitalization levels.

It seems impossible to manage the digital transformation of the economy without an appropriate legislative framework, therefore, regulatory and legal acts have been adopted to regulate activities at various levels.

Decree of the President of Russia dated May 7, 2018 No. 204 "On national goals and strategic objectives of the development of the Russian Federation for the period up to 2024" set the task of transforming priority sectors of the economy and social sphere, including agriculture, through the introduction of digital technologies and platform solutions [3].

There are seven main directions of digital transformation of agriculture and scientific and 
technological development in the field of "Digital agriculture", which implies the introduction in the constituent entities of the Russian Federation of at least six projects of a complete innovative complex scientific and technical cycle of end-to-end digital systems: "Digital technologies in agro-industrial complex management", "Digital land use", "Smart field", "Smart garden", "Smart greenhouse", "Smart farm", based on modern competitive domestic technologies, methods, algorithms.

Currently, economic resilience is recognized as a vital factor in the survival of the rural population [4].

As part of the digitalization of the agricultural sector in 2021, a wider list of areas for the use of targeted concessional loans for the introduction of digital technologies and the automation of agricultural enterprises has been identified. In particular, the concessional shortterm lending packages for up to 1 year and concessional investment loans from 2 to 5 years were provided. The first direction of lending implies the informatization and digitalization of agricultural production and the processing of own products, including the maintenance of machinery and equipment in this area.

In particular, the dairy sector of the industry gets the opportunity to use the loan funds for technical support of hardware and software and labeling of certain dairy product types.

Concessional investment lending may be aimed at expanding the fleet of agricultural machinery with automatic driving systems, spot application of materials, yield mapping, precise farming, or the data collecting and transmitting equipment [5].

Table 1. Costs of deployment and use of digital technologies in the North Caucasian Federal District in 2019.

\begin{tabular}{|l|c|c|c|c|c|}
\hline \multirow{2}{*}{\multicolumn{1}{|c|}{ Region }} & Total & \multicolumn{4}{c|}{ Including } \\
\cline { 2 - 6 } & \multirow{2}{*}{$\begin{array}{c}\text { RUR } \\
\text { mIn }\end{array}$} & \multicolumn{2}{|c|}{ Internal expenses } & \multicolumn{2}{c|}{ External expenses } \\
\cline { 3 - 6 } & RUR mln & $\mathbf{\%}$ & RUR mIn & \% \\
\hline North Caucasian federal district & 13802.3 & 12405.51 & 89.9 & 1396.80 & 10.1 \\
\hline The Republic of Dagestan & 1404.3 & 1368.03 & 97.4 & 36.30 & 2.6 \\
\hline The Republic of Ingushetia & 306.9 & 304.50 & 99.2 & 2.41 & 0.8 \\
\hline Kabardino-Balkar Republic & 572.0 & 514.82 & 90.0 & 57.21 & 10.0 \\
\hline Karachay-Cherkess Republic & 651.5 & 590.01 & 90.6 & 61.50 & 9.4 \\
\hline Republic Northern Ossetia-Alania & 1088.0 & 1004.05 & 92.3 & 84.01 & 7.7 \\
\hline The Chechen Republic & 2298.9 & 2222.90 & 96.7 & 76.01 & 3.3 \\
\hline Stavropol Territory & 7480.6 & 6401.23 & 85.6 & 1079.40 & 14.4 \\
\hline
\end{tabular}

*Source: Russia region data [9].

In the North Caucasian Federal District in 2019, the cost of introducing and using digital technologies amounted to $13,802.3$ RUR mln, of which $89.9 \%$ are internal costs and $10.1 \%$ are external. Analyzing by region, it can be seen that the largest expenditures on digital technologies are observed in the Stavropol Territory at $7480.6 \%$, which is $54.2 \%$ in the share of the amount spent in the region.

In the Kabardino-Balkarian Republic, 572 mln RUR was invested in the deployment and use of digital technologies, where internal costs account for $90.0 \%$ in the amount of $514.8 \mathrm{mln}$ RUR and for external costs - 10\%, which amounted to $57.2 \mathrm{mln}$ RUR.

The Kabardino-Balkarian Republic lags behind in information and communication technologies in general in Russia. Medium and small businesses have limited funds to pay for these services, everything is only at the nascent stage, and the level of IT services provided by external organizations is low as well. Therefore, the transformational transformation of the agro-industrial complex in the context of digitalization is the main prerogative of its modern development. The most important is the formation of territorial-innovative models of the agrarian sector of the republic's economy and increasing the volume of the gross domestic product. There is some improvement in the investment climate with a simultaneous 
improvement in its legal regulation. In particular, in the field of the agro-industrial complex, production capacities for the production of canned products have been expanded with the simultaneous creation of additional jobs.

If we assess the economic indicators of the region's agro-industrial complex, then, first of all, we will single out the volume of production by the end of 2020 of all agricultural producers in the amount of 61.4 RUR bln, the result is higher than the level of 2019 by $10 \%$. Land reclamation measures are being intensively implemented in the republic within the framework of the regional project "Export of agricultural products" and the departmental program "Development of the land reclamation complex in Russia". Within this program, 7.9 th ha of irrigated land were commissioned in 2020 , which is $22.2 \%$ higher than the program parameters.

Table 2. Dynamics of the main indicators of export of agricultural products of the Kabardino-Balkarian Republic.

\begin{tabular}{|l|c|c|c|c|c|c|}
\hline \multirow{2}{*}{ By product types } & \multicolumn{3}{|c|}{$\begin{array}{c}\text { Export as of 30.06, USD mIn. } \\
\text { USA }\end{array}$} & \multicolumn{3}{c|}{ Average price, USD/ton } \\
\cline { 2 - 7 } & $\mathbf{2 0 1 9}$ & $\mathbf{2 0 2 0}$ & $\mathbf{\%}$ & $\mathbf{2 0 1 9}$ & $\mathbf{2 0 2 0}$ & $\mathbf{\%}$ \\
\hline Oil and fat industry products & 0.0 & - & - & 1069.3 & - & - \\
\hline Grain & 0.4 & 2.0 & by 4.5 times & 847.1 & 3046.3 & by 3.6 times \\
\hline Fish and seafood & - & - & - & - & - & - \\
\hline Meat and dairy products & 0.2 & 0.1 & -62.2 & 858.9 & 1026.2 & +19.5 \\
\hline $\begin{array}{l}\text { Food and processing industry } \\
\text { products }\end{array}$ & 2.5 & 2.7 & +8.5 & 1036.3 & 1035.9 & - \\
\hline Other agricultural products & 2.9 & 13.5 & by 4.6 times & 715.3 & 1015.3 & +41.9 \\
\hline Total & 6.0 & 18.3 & by 3 times & 835.6 & 1099.7 & +31.6 \\
\hline
\end{tabular}

*Source: [6].

The increase in the export of products by more than 3 times is due to grain farming exported to the near and far abroad (Azerbaijan, Kazakhstan, Belarus, Iran, etc.). Dairy and sour milk products, poultry meat, confectionery, mineral water, fresh fruits, etc. are exported as well. [7]. Pursuant to forecasts of the Ministry of Economy of the KBR, it is assumed that in 2020 the volume of exports of the Kabardino-Balkarian Republic will amount to 30 USD $\mathrm{mln}$, or $140.8 \%$ in relation to the level of 2019 .

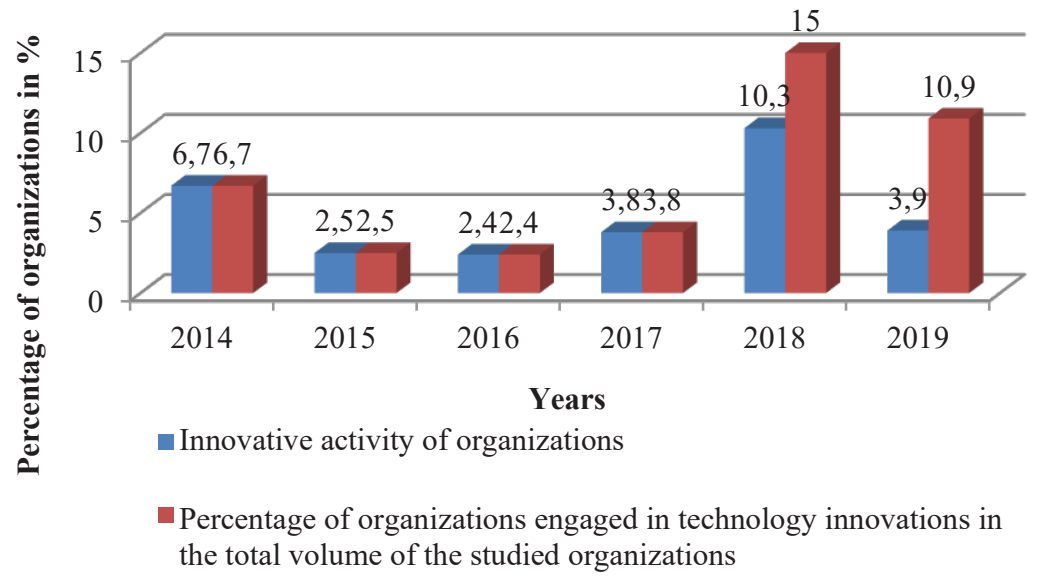

Fig. 2. Innovative activity of organizations in the Kabardino-Balkarian Republic.

In 2019, the innovative activity of the organization in the Kabardino-Balkarian Republic amounted to $3.9 \%$ against $10.3 \%$ in 2018 . The decline in innovation activity was almost twofold (by 6.4 percentage points). The implementation of technological innovations in 
organizations in the reporting year in comparison with the previous period decreased by $4.1 \%$ and amounted to $10.9 \%$.

For agro-industrial formations, the digitalization of agriculture will reduce costs by $23 \%$, since the average cost savings for land use using GPS navigation technologies is $11-14 \%$, with differential fertilization $-8-12 \%$, and thanks to parallel driving systems $-8-13 \%$ [8].

The volume of innovation implementation reflects an indicator that characterizes in monetary terms the costs of various types of technological innovation in the activities of the organization.

Based on the foregoing, let us consider the dynamics of technological costs within the NCFD.

Table 3. Dynamics of costs for technological innovation in the NCFD.

\begin{tabular}{|c|c|c|c|c|c|c|}
\hline \multirow[b]{2}{*}{ Region } & \multicolumn{2}{|r|}{2016} & \multicolumn{2}{|r|}{2017} & \multicolumn{2}{|c|}{2018} \\
\hline & $\begin{array}{c}\text { RUR } \\
\text { mln }\end{array}$ & $\begin{array}{l}\text { in } \% \text { of the } \\
\text { total volume of } \\
\text { goods shipped, } \\
\text { works and } \\
\text { services } \\
\text { performed }\end{array}$ & $\begin{array}{c}\text { RUR } \\
\text { mln }\end{array}$ & $\begin{array}{l}\text { in } \% \text { of the } \\
\text { total volume of } \\
\text { goods shipped, } \\
\text { works and } \\
\text { services } \\
\text { performed }\end{array}$ & $\begin{array}{c}\text { RUR } \\
\text { mln }\end{array}$ & $\begin{array}{c}\text { in \% of the } \\
\text { total } \\
\text { volume of } \\
\text { goods } \\
\text { shipped, } \\
\text { works and } \\
\text { services } \\
\text { performed }\end{array}$ \\
\hline $\begin{array}{l}\text { North Caucasian } \\
\text { federal district }\end{array}$ & 7896.5 & 1.4 & 8956.8 & 1.54 & 7142.4 & 0.8 \\
\hline $\begin{array}{l}\text { The Republic of } \\
\text { Dagestan }\end{array}$ & 55.9 & 0.1 & 20.1 & 0.0 & 672.4 & 0.2 \\
\hline $\begin{array}{l}\text { Republic of } \\
\text { Ingushetia }\end{array}$ & - & - & 0.7 & 0.0 & - & - \\
\hline $\begin{array}{l}\text { Kabardino-Balkar } \\
\text { Republic }\end{array}$ & 86.2 & 0.3 & 296.5 & 0.9 & 326.0 & 1.0 \\
\hline $\begin{array}{l}\text { Karachay- } \\
\text { Cherkess Republic }\end{array}$ & 8.1 & 0.0 & 26.7 & 0.1 & 12.9 & 0.0 \\
\hline $\begin{array}{l}\text { Republic Northern } \\
\text { Ossetia-Alania }\end{array}$ & 19.4 & 0.1 & 49.5 & 0.2 & 36.1 & 0.1 \\
\hline $\begin{array}{l}\text { The Chechen } \\
\text { Republic }\end{array}$ & 39.4 & 0.1 & 77.5 & 0.4 & 13.2 & 0.0 \\
\hline $\begin{array}{l}\text { Stavropol } \\
\text { Territory }\end{array}$ & 7687.4 & 2.0 & 8485.8 & 2.1 & 6081.8 & 1.4 \\
\hline
\end{tabular}

* Source: Russia region data [9].

In general, in the NCFD, costs are at the level of 7142.4 RUR mln and the indicator is lower than the previous periods, respectively, by 1,814.4 and 751.1 RUR mln. The cost of technological innovation in the Kabardino-Balkarian Republic increased compared to 2016 by 239.8 RUR mln and amounted to 326.0 RUR mln, which indicates the intensification of innovation processes over the past two years. In relation to the total volume of goods shipped, works and services performed in 2018, innovation costs amounted to $1.0 \%$, which is more than 3 times more than in 2016. In comparison with the rest of the subjects of the North Caucasian Federal District in 2018, the largest share of costs falls on innovation processes in the Stavropol Territory (i.e. 1.4\% or 6081.8 RUR mln). [7].

\section{Conclusion}

The process of globalization of the digitalization market is essentially a way of life, the basis for state management of sectors of the economy, society, and business. The digital transformation of the agricultural sector is gaining momentum, allowing to increase profitability by 2-3 times, the efficiency of the agro-industrial complex, contributing to 
leveling risks, reducing costs and production losses, introducing modern agricultural technologies such as remote sensing of land, digital twins of fields, precision farming technologies based on digital platforms and artificial intelligence.

The pace of implementation of technical and technological modernization and innovation is not yet sufficient for the introduction and implementation of these platforms, farmers need digitalization tools, solve the problem of a shortage of personnel with skills in working with digital products and technologies, and the key role of the state here should be reduced to a clear development of the development vector digitalization in all areas, which would ensure the competitiveness of production.

\section{References}

1. Skolkovo Digital Russia Methodology (2019) https://finance.skolkovo.ru

2. I. Yu. Merzlov, E. V. Shilova, E. A. Sannikova, M. A. Sedinin, Economics, Entrepreneurship and Law, 10(9), 2379 (2020)

3. Decree of the President of the Russian Federation of May 7, 2018 «On national goals and strategic objectives of the development of the Russian Federation for the period up to 2024»»

4. A. K Dikinov, S. A. Chernyavskaya, F. E. Karaeva, K. N. Adaeva, S. A. Lyanova, Journal of Interdisc Iplinary Research, 10.2/13, 86 (2020)

5. Materials of the Ministry of Agriculture of the Russian Federation, https://pravitelstvo.kbr.ru

6. Main export indicators of agro-industrial complex of Kabardino-Balkarian Republic, https://aemcx.ru

7. N. H. Kairova, R. E. Shokumova, Collection of Scientific Works of the III International Scientific and Practical Forum, 325 (2020)

8. Digital agriculture - opportunities and potential risks, https://ecfs.msu.ru

9. Regions of Russia. Socio-economic indicators. 2018 (Rosstat, 2018) http://www.gks.ru

10. A. M. Magomedov, Economics and management: problems, solutions, 1, 12(96), 88 (2019) 